IRA-International Journal of Technology \& Engineering

ISSN 2455-4480; Vol.03, Issue 03 (2016)

Institute of Research Advances

http://research-advances.org/index.php/IRAJTE

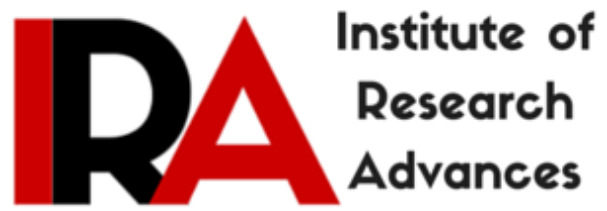

\title{
Anti Corrosion Ability and Biocidal Efficiency of Surfactants on Mild Steel in Aqueous Environment
}

\section{K. N. Manonmani,}

Research Scholar in Chemistry, Department of chemistry, Mother Teresa Women's

University, Kodaikanal-624 102, Tamil Nadu, India.

\section{P. Manjula,}

Associate Professor/Head, Department of Chemistry, APA College for Women,

Palani, Tamil Nadu, India.

\section{T. Vennila,}

Sri Sairam College of Engineering, Chennai,-600 044.Tamil Nadu, India.

DOI: http://dx.doi.org/10.21013/jte.v3.n3.p2

\section{How to cite this paper:}

Manonmani, K., Manjula, P., \& Vennila, T. (2016). Anti Corrosion Ability and

Biocidal Efficiency of Surfactants on Mild Steel in Aqueous Environment. IRA-

International Journal of Technology \& Engineering (ISSN 2455-4480), 3(3).

doi:http://dx.doi.org/10.21013/jte.v3.n3.p2

(C) Institute of Research Advances

(cc) EY-NC

This works is licensed under a Creative Commons Attribution-Non Commercial 4.0 International License subject to proper citation to the publication source of the work.

Disclaimer: The scholarly papers as reviewed and published by the Institute of Research Advances (IRA) are the views and opinions of their respective authors and are not the views or opinions of the IRA. The IRA disclaims of any harm or loss caused due to the published content to any party. 


\begin{tabular}{|c|}
\hline ABSTRACT \\
\hline 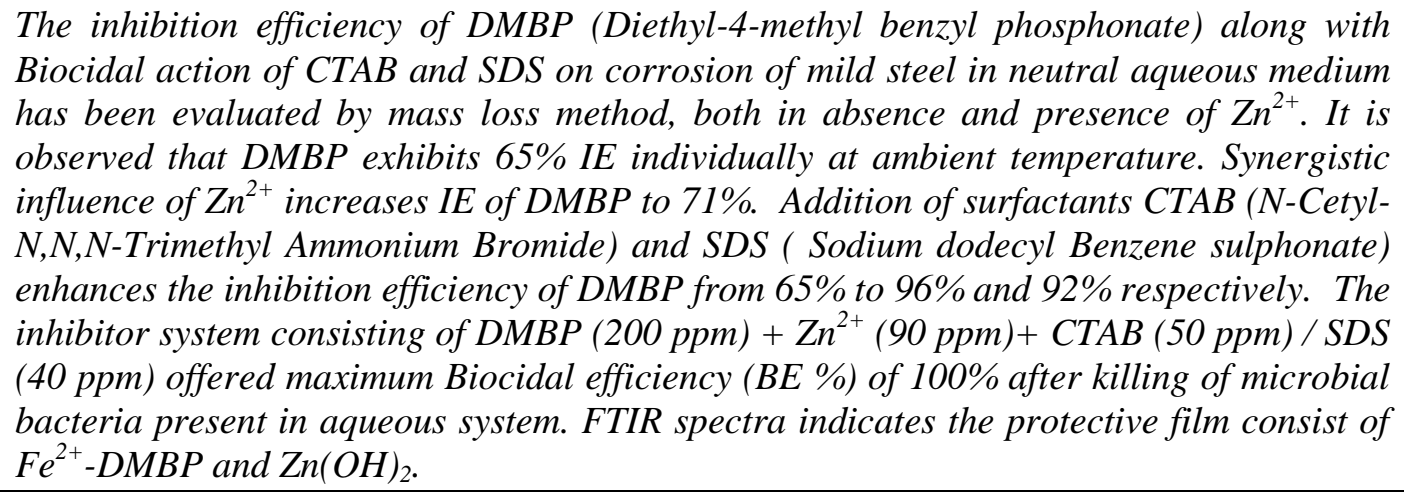 \\
\hline
\end{tabular}

Key words: carbon steel, surfactant, Biocidal efficiency, synergistic effect and Zobell medium.

\section{Introduction}

In the field of inhibition, scientists are persistent in seeking better and more efficient ways of combating corrosion of metals $(1,2)$. The challenge is to develop a new class of corrosion inhibitors to protect the materials, which are environment friendly under various conditions. To be effective an inhibitor must also transfer water from the metal surface, interact with anodic or cathodic reaction sites to retard the oxidation and reduction corrosion reaction, and prevent transportation of water and corrosion active species on the metal surface. Surfactant inhibitors have many advantages, for example, high inhibition efficiency, low price, low toxicity and easy protection (3). Moreover, the investigation of surfactants adsorbed on metal surface is extremely important in electrochemical studies such as corrosion inhibition, adhesion, lubrication and detergency. The effective type of corrosion inhibitors for these applications is film forming inhibitors. Nowadays, surfactants are widely used and find a very large number of applications in the petroleum industry. This is attributed to their significant capability to influence the properties of surfaces and interfaces. Mild steel widely employed in most industries due to easy fabrication of various reaction vessels such as cooling tower tanks, pipelines etc. and of low cost. In the presence anti corrosive ability of sodium salt of DMBP and the surfactants CTAB and SDS in controlling corrosion of mild steel in aqueous medium are investigated. To inhibit MIC (microbially induced corrosion) in water, Biocidal efficiency (4) of surfactant selected in this study is also determined.

\section{MATERIALS}

\section{Materials and Methods}

\section{Preparation of Mild steel specimens}

Mild steel specimens were chosen from the same sheet of the following composition $0.1 \% \mathrm{C}, 0.026 \% \mathrm{~S}, 0.06 \% \mathrm{P}, 0.4 \% \mathrm{Mn}$ and the rest Iron and the dimensions of $1.0 \times 4.0 \times 0.2 \mathrm{~cm}$. Prior to all measurements, the carbon steel specimens were mechanically abraded (5) with different types of emery papers (Grade 320 - 400- 600800-1000-1200), degreased with acetone rinsed with distilled water, dried and weighed before immersion in the experimental solution. These specimens were used for gravimetric measurements 


\section{Chemical and reagents}

All the chemicals and reagents used were of Analar/Sigma Aldrich Grade

\section{Preparation of inhibitor solution Diethyl 4- Methyl Benzyl Phosphonate (DMBP)}

$5 \mathrm{ml}$ of the DMBP is subjected to alkaline hydrolysis with sodium hydroxide. The sodium salt is dried and recrystallised using distilled water. $1 \mathrm{~g}$ of the sodium salt is distilled in 1 litre of DD water and made upto $1000 \mathrm{ml}$. a hundred fold dilutions is exactly $10 \mathrm{ppm}$ of inhibitor concentration.

\section{Preparation of Sodium Chloride Solution}

Exactly $4.9 \mathrm{~g}$ of sodium chloride was dissolved in double distilled water and made up to $500 \mathrm{ml}$ in a standard measuring flask. A hundred fold dilution yields exactly $60 \mathrm{ppm}$ of $\mathrm{Cl}^{-}$ion concentration.

\section{Preparation of Zinc Sulphate solution}

Exactly $2.2 \mathrm{~g}$ of zinc sulphate was dissolved in double distilled water and made up to $500 \mathrm{ml}$ in standard measuring flask. A hundred fold dilution yields exactly $10 \mathrm{ppm}$ of $\mathrm{Zn}^{2+}$ ion concentration.

\section{Preparation of CTAB/SDS solution}

Exactly $1 \mathrm{~g}$ of CTAB/SDS was dissolved in double distilled water and made up to $100 \mathrm{ml}$ in standard measuring flask. A hundred fold dilution yields exactly $10 \mathrm{ppm}$ of CTAB/SDS concentration.

\section{Preparation of Zobell medium}

Zobell medium was prepared by dissolving $5 \mathrm{~g}$ of peptone, $1 \mathrm{~g}$ of yeast extract, 0.1 $\mathrm{g}$ of Potassium dehydrate phosphate and $15 \mathrm{~g}$ of agar- agar in one litre of double distilled water. The medium was sterilized by applying 15 pounds per square inch for 15 minutes in an autoclave.

\section{METHODS}

\section{Mass loss measurements}

Carbon steel specimens in triplicate were immersed in $100 \mathrm{ml}$ of solutions containing various concentrations of the inhibitor in the presence and absence of $\mathrm{Zn}^{2+}$ for three hours. The weight of the specimens before and after immersion was determined using a Shimadzu balance, model AY62. The corrosion products were cleansed with Clarke's solution (6). The inhibition efficiency (IE) was then calculated using the equation.

Efficiency of Inhibitors $(\%)=\mathrm{WL}_{\mathrm{w}}-\mathrm{WL}_{\mathrm{i}} / \mathrm{WL}_{\mathrm{w}}$ X 100

Where $\mathrm{WL}_{\mathrm{w}}$ is the weight loss without inhibitor and $\mathrm{WL}_{\mathrm{i}}$ is the weight loss with inhibitor.

\section{Determination of Biocidal efficiency of the system}

Diethyl-4-methyl benzyl phosphonate- $\mathrm{Zn}^{2+}$ formulation which offered the best corrosion inhibition efficiency was selected. The biocidal efficiency of N-Cetyl-N,N,NTrimethyl Ammonium Bromide (CTAB) and Sodium dodecyl benzene sulphonate (SDS) in the presence of this formulation and also the effect of CTAB on the corrosion inhibition efficiency of this system were determined. 
Various concentration of CTAB Viz 10 ppm , 50 ppm, 100 ppm, 150 ppm and $200 \mathrm{ppm}$ were added to the formulation consisting of the inhibitor system. Polished and degreased carbon steel specimen in triplicate were immersed in these environments for a period of 3 hours. After 3 hours, $1 \mathrm{ml}$ each of test solutions from environments was pipetted out into sterile petridishes each containing about $20 \mathrm{ml}$ of the sterilize zobell medium. The petridishes were then kept in a sterilized environment inside the laminar flow system. Flow system fabricated and supplied by CEERI-Pilani for 24 hours. The total viable heterotropic bacterial colonies were counted using a bacterial colony counter.

The corrosion inhibition efficiencies of the formulation consisting of the inhibitor in the presence of various concentrations of CTAB and SDS were determined in the same way as discussed. Similarly the experiment was done with SDS. The materials used and methods employed in the present study have been presented.

\section{SURFACE EXAMINATION STUDIES}

\section{Surface analysis by FTIR spectroscopic study}

After the immersion period of three hours in various environments, the specimens are taken out of the test solutions and dried. The film formed on the surface is scratched carefully and it is thoroughly mixed so as to make it uniform throughout. FTIR spectrum of the powder ( $\mathrm{KBr}$ pellet) is recorded using Perkin-Elmer 1600 FTIR spectrophotometer with a resolving power of $400 \mathrm{~cm}^{-1}$.

\section{Surface analysis by SEM}

SEM micrographs were taken to using VEGA 3 TESCAN model at Department of Chemistry, Gandhi gram Rural Institute, Gandhi gram, Dindigul, Tamilnadu, India.

\section{Result and Discussion}

The adsorption process is influenced by the phosphonic acid groups present in the inhibitor molecule which forms the protective complex Fe-DMBP and the distribution of charge (7) in the inhibitor molecule on to the metal surface. At higher concentration of DMBP aggressive $\mathrm{Cl}^{-}$ion enhances the corrosivity of the metal surface due to desorption of the inhibitor molecules on the surface.

Phosphonic acids can be adsorbed on the mild steel surface by the interaction between lonepair of electron of oxygen and phosphorus atoms of the inhibitor and the metal surface. This process is facilitated by the presence of vacant orbitals of low energy in ion atoms, as observed in the transition metals. 
Table 1: Corrosion rates of mild steel in neutral aqueous environment $\left(\mathrm{Cl}^{-}=60 \mathrm{ppm}\right)$ in the presence and absence of inhibitor and the inhibition efficiencies obtained by the weight-loss method.

Inhibitor system: $\mathrm{DMBP}+\mathrm{NaCl}(60 \mathrm{ppm})$ system

Immersion Time: 3 Hours

$\mathrm{pH}=7$

\begin{tabular}{|l|l|l|l|l|l|c|}
\hline S.No & $\begin{array}{l}\text { Conc. of } \\
\text { DMBP } \\
(\mathrm{ppm})\end{array}$ & $\begin{array}{l}\text { Conc. of } \\
\mathrm{Zn}^{2+} \\
(\mathrm{ppm})\end{array}$ & $\begin{array}{l}\text { Wt.loss } \\
(\mathrm{g})\end{array}$ & $\begin{array}{c}\text { CR } \\
(\mathrm{mmpy})\end{array}$ & $\begin{array}{l}\text { Surface } \\
\text { coverage } \\
(\theta)\end{array}$ & $\begin{array}{c}\text { IE } \\
(\%)\end{array}$ \\
\hline 1. Blank & 0 & 0 & 0.0025 & 0.9297 & - & - \\
\hline 2. & 75 & 0 & 0.001825 & 0.6787 & 0.2700 & 27 \\
\hline 3. & 100 & 0 & 0.0017 & 0.6322 & 0.3200 & 32 \\
\hline 4. & 150 & 0 & 0.0011 & 0.4090 & 0.5600 & 56 \\
\hline 5. & 200 & 0 & 0.000875 & 0.3254 & 0.6500 & 65 \\
\hline 6. & 300 & 0 & 0.00105 & 0.3904 & 0.5800 & 58 \\
\hline 7. & 350 & 0 & 0.00115 & 0.4276 & 0.5400 & 54 \\
\hline
\end{tabular}

Figure 1: Plot of inhibition efficiency of carbon steel as a function of various concentration of DMBP at $\mathrm{pH} 7$

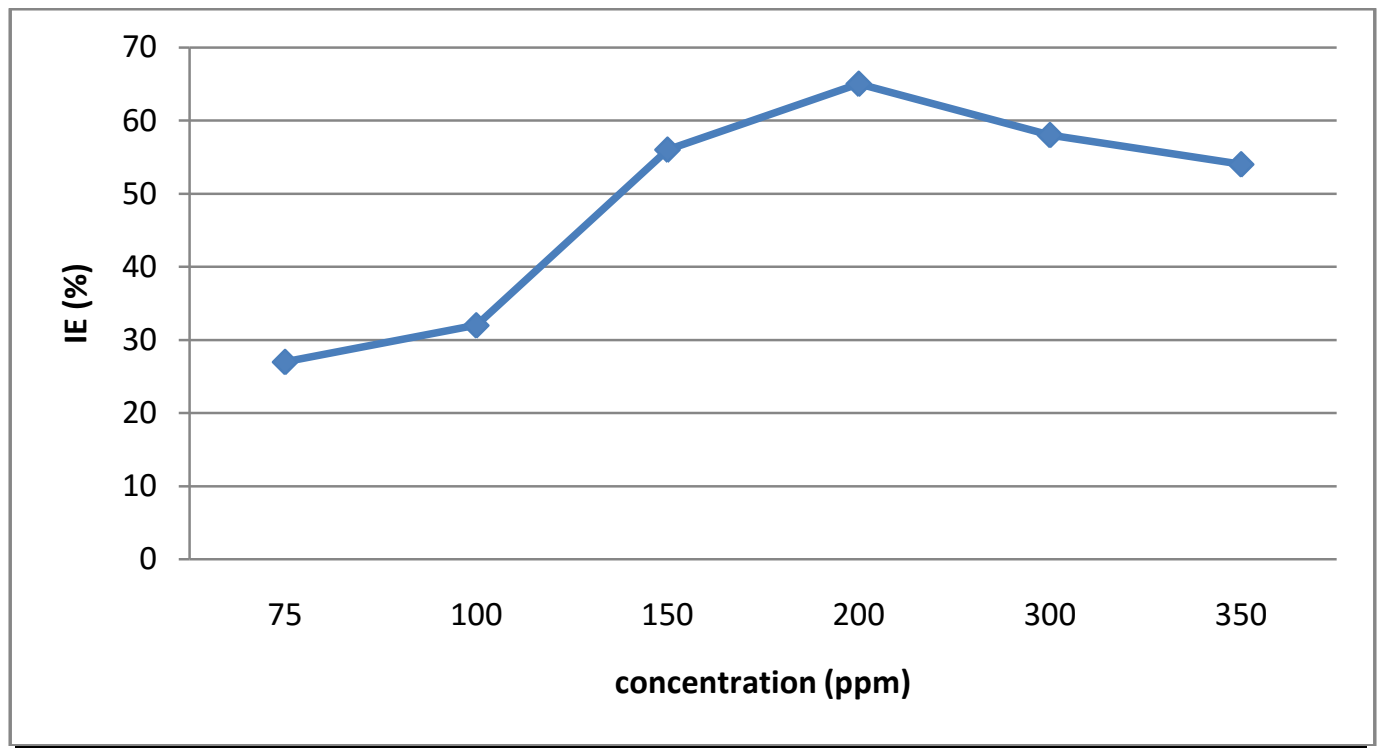

\subsection{Influence of $\mathrm{Zn}^{2+}$ ion on IE of DMBP}

The inhibitive effect of $\mathrm{Zn}^{2+}$ and its synergistic influence on the IE of DMBP is given in Tables 2 and 3 and also graphically represented in Figure 2 and 3 respectively. It is observed from the table 2 that when the concentration of $\mathrm{Zn}^{2+}$ ions is increases IE also increases. After reaching optimum concentration of $90 \mathrm{ppm}$ IE is found to decrease with rise in concentration. It is observed from the Table 3 that a synergistic effect is exist between DMBP and $\mathrm{Zn}^{2+}$. For example $90 \mathrm{ppm}$ of $\mathrm{Zn}^{2+}$ has $66.8 \%$. $200 \mathrm{ppm}$ of DMBP has $65 \%$ IE. Interestingly their combination has $71 \%$ IE. This suggests that a synergism exist between $\mathrm{Zn}^{2+}$ and DMBP. 
Table 2: Corrosion rates of mild steel in neutral aqueous environment $\left(\mathrm{Cl}^{-}=60 \mathrm{ppm}\right)$ in the presence and absence of inhibitor and the inhibition efficiencies obtained by the weight-loss method.

Inhibitor system: $\mathrm{NaCl}(60 \mathrm{ppm})+\mathrm{Zn}^{2+}$

$\mathrm{pH}=7$

Immersion time: 3 Hours

\begin{tabular}{|l|l|l|l|l|l|}
\hline S.No & $\begin{array}{l}\text { Conc. of } \\
\text { DMBP } \\
(\mathrm{ppm})\end{array}$ & $\begin{array}{l}\text { Conc. of } \\
\mathrm{Zn}^{2+}(\mathrm{ppm})\end{array}$ & $\begin{array}{l}\text { CR } \\
(\mathrm{mmpy})\end{array}$ & $\begin{array}{l}\text { Surface } \\
\text { coverage }(\theta)\end{array}$ & $\begin{array}{l}\text { IE } \\
(\%)\end{array}$ \\
\hline 1. Blank & 0 & 0 & 0.9297 & - & - \\
\hline 2. & 0 & 50 & 0.4369 & 0.5300 & 53 \\
\hline 3. & 0 & 60 & 0.3719 & 0.6000 & 60 \\
\hline 4. & 0 & 70 & 0.3347 & 0.6400 & 64 \\
\hline 5. & 0 & 90 & 0.3086 & 0.6680 & 66.8 \\
\hline 6. & 0 & 100 & 0.3719 & 0.6000 & 60 \\
\hline 7. & 0 & 120 & 0.4183 & 0.5500 & 55 \\
\hline
\end{tabular}

Figure 2: Plot of inhibition efficiency of carbon steel as a function of various concentration of DMBP at $\mathrm{pH} 7$

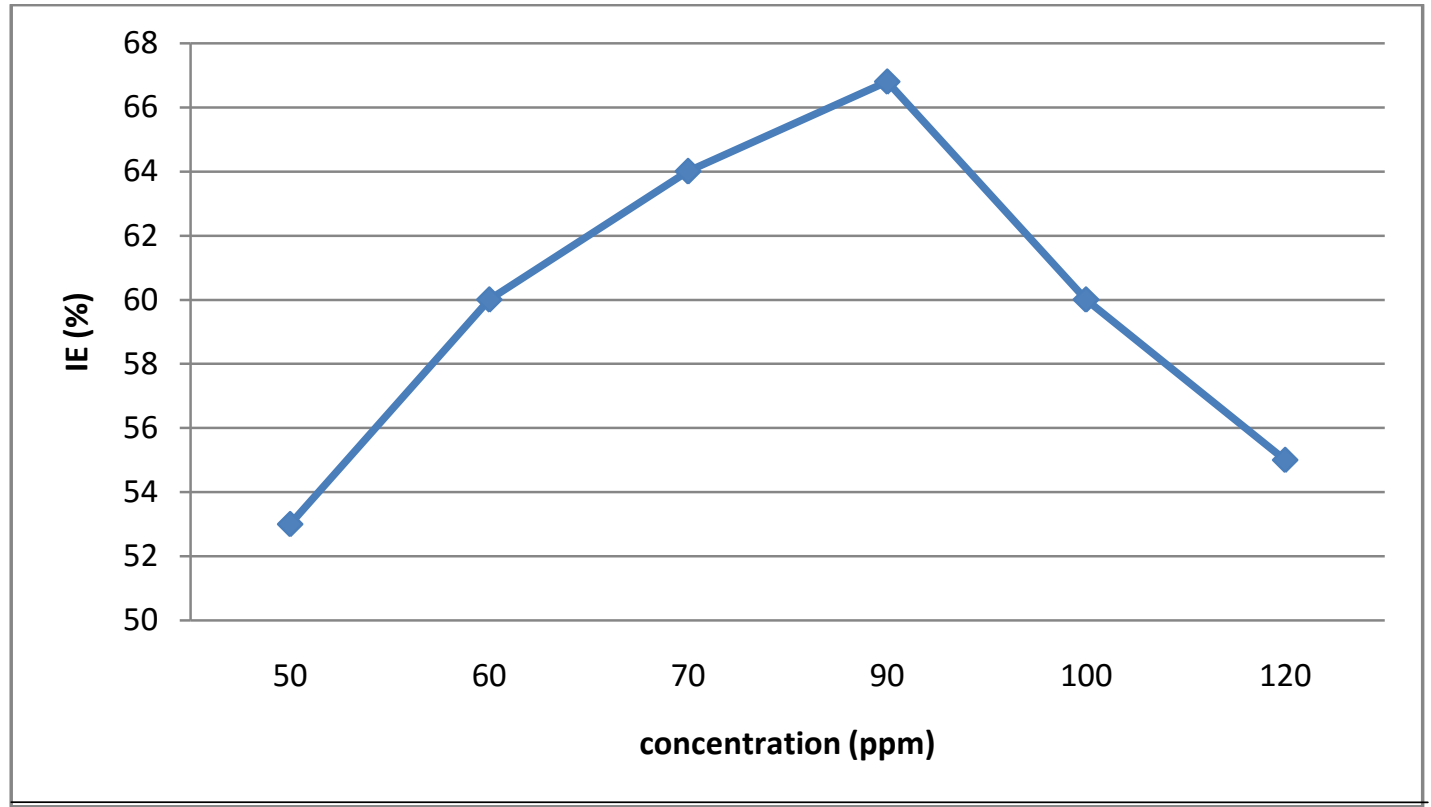


Table 3: Results of corrosion rates (CR) and inhibition efficiencies (IE) of mild steel immersed in aqueous medium containing ( $60 \mathrm{ppm} \mathrm{Cl}^{-}$ion) in the absence and presence of inhibitors by weight loss method

\begin{tabular}{|c|c|c|c|c|c|c|c|c|c|c|}
\hline \multirow{4}{*}{$\begin{array}{l}\text { Conc. } \\
\text { Of } \\
\text { DMB } \\
\text { P } \\
(\mathrm{ppm}) \\
0\end{array}$} & \multicolumn{10}{|c|}{ Conc. Of $\mathrm{Zn}^{2+}$} \\
\hline & \multicolumn{2}{|l|}{$0 \mathrm{ppm}$} & \multicolumn{2}{|l|}{$20 \mathrm{ppm}$} & \multicolumn{2}{|l|}{$60 \mathrm{ppm}$} & \multicolumn{2}{|l|}{90 ppm } & \multicolumn{2}{|l|}{$120 \mathrm{ppm}$} \\
\hline & $\begin{array}{l}\text { CR } \\
\text { (mmpy) }\end{array}$ & $\begin{array}{l}\mathrm{IE} \\
(\%)\end{array}$ & $\begin{array}{l}\text { CR } \\
\text { (mmpy) }\end{array}$ & $\begin{array}{l}\mathrm{IE} \\
(\%)\end{array}$ & $\begin{array}{l}\text { CR } \\
\text { (mmpy) }\end{array}$ & $\begin{array}{l}\mathrm{IE} \\
(\%)\end{array}$ & $\begin{array}{l}\text { CR } \\
\text { (mmpy) }\end{array}$ & $\begin{array}{l}\mathrm{IE} \\
(\%)\end{array}$ & $\begin{array}{l}\text { CR } \\
\text { (mmpy) }\end{array}$ & $\begin{array}{l}\mathrm{IE} \\
(\%)\end{array}$ \\
\hline & 0.9297 & - & 0.7521 & 19.1 & 0.3719 & 60 & 0.3086 & $\begin{array}{l}66 . \\
8\end{array}$ & 0.4183 & 55 \\
\hline 10 & 0.8553 & 8 & 0.7438 & 20 & 0.4462 & 52 & 0.3049 & $\begin{array}{l}67 . \\
2\end{array}$ & 0.4128 & 55.6 \\
\hline 20 & 0.7438 & 20 & 0.7252 & 22 & 0.4276 & 54 & 0.3012 & $\begin{array}{l}67 . \\
6\end{array}$ & 0.4072 & 56.2 \\
\hline 50 & 0.7066 & 24 & 0.6322 & 32 & 0.3904 & 58 & 0.2975 & 68 & 0.3904 & 58 \\
\hline 75 & 0.6787 & 27 & 0.5578 & 40 & 0.3719 & 60 & 0.2949 & $\begin{array}{l}68 . \\
3\end{array}$ & 0.3830 & 59 \\
\hline 100 & 0.6322 & 32 & 0.4462 & 52 & 0.3254 & 65 & 0.2930 & $\begin{array}{l}68 . \\
5\end{array}$ & 0.3719 & 60 \\
\hline 150 & 0.4090 & 56 & 0.4183 & 55 & 0.3068 & 67 & 0.2901 & $\begin{array}{l}68 . \\
8\end{array}$ & 0.3533 & 62 \\
\hline 200 & 0.3254 & 65 & 0.3904 & 58 & 0.2975 & 68 & 0.2696 & 71 & 0.3347 & 64 \\
\hline 300 & 0.3904 & 58 & 0.3719 & 60 & 0.3254 & 65 & 0.3068 & 67 & 0.3719 & 60 \\
\hline 350 & 0.4276 & 54 & 0.3570 & 61.6 & 0.3161 & 66 & 0.2975 & 68 & 0.3719 & 60 \\
\hline
\end{tabular}

Inhibitor system: $\mathrm{DMBP}+\mathrm{Zn}^{2+}$ ion

Immersion Time: 3 hours

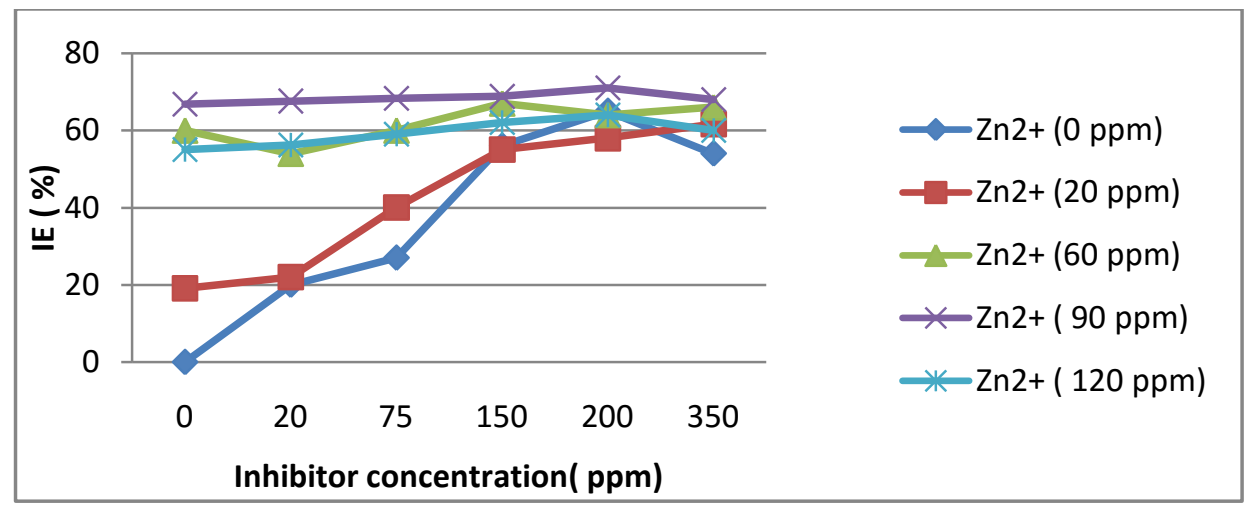

Figure 3: Plot of inhibition efficiency of carbon steel as a function of various concentration of DMBP and $\mathrm{Zn}^{2+}$ at $\mathrm{pH} 7$ 


\subsection{Biocidal efficiency of CTAB on binary inhibitor $\left(\mathrm{DMBP}-\mathrm{Zn}^{2+}\right)$ system}

The biocidal efficiency (8-12) of DMBP- $\mathrm{Zn}^{2+}-\mathrm{CTAB}$ system is given in Table 6 . It is found that $\mathrm{CTAB}$ shows very good biocidal efficiency in a wide concentration range (i.e., 10 to $250 \mathrm{ppm}$ ). It seems that CTAB has biocidal activity as it aggregates together. The number of bacterial colonies formed as a function of concentration of CTAB in presence of DMBP- $\mathrm{Zn}^{2+}-\mathrm{CTAB}$ system is shown in Fig. 7.Mild steel widely used in the fabrication of cooling water pipes and heat exchanger tubes(13,14). Fouling and microbial corrosion causes many problems and if the water used in these systems contain $1 \times 10^{4} \mathrm{CFU} / \mathrm{ml}$ then there is no problem of microbial corrosion. When $10 \mathrm{ppm}$ of CTAB along with the inhibitor DMBP- $\mathrm{Zn}^{2+}$ is added unacceptable value of $2.4 \times 10^{3} \mathrm{CFU} / \mathrm{ml}$ is counted. $50 \mathrm{ppm} \mathrm{CTAB}$ in the same system has shown no sign of colonies in the system. It proves that a mixture of $60 \mathrm{ppm} \mathrm{Cl}^{-}, 100 \mathrm{ppm} \mathrm{DMBP}, 50 \mathrm{ppm} \mathrm{Zn}^{2+}$ and $50 \mathrm{ppm}$ CTAB provides $100 \%$ biocidal efficiency. The $100 \%$ biocidal efficiency as evidenced by reported results in earlier works (9-15) proved that the cationic surfactant CTAB along with other organic and inorganic inhibitors may be applied as an excellent biocide in cooling water systems.

Table 4: Corrosion rate of mild steel in neutral aqueous environment containing CTAB $\left(\mathrm{Cl}^{-}=60 \mathrm{ppm}\right)$ in the absence of inhibitor and the inhibition efficiencies obtained by weight loss method.

\begin{tabular}{|l|l|l|}
\hline $\begin{array}{l}\text { Conc. of CTAB } \\
(\mathrm{ppm})\end{array}$ & $\begin{array}{l}\text { Corrosion rate } \\
(\mathrm{mmpy})\end{array}$ & $\begin{array}{l}\text { Inhibition } \\
\text { efficiency (\%) }\end{array}$ \\
\hline 0 & 0.9297 & - \\
\hline 10 & 0.3719 & 60 \\
\hline 20 & 0.3347 & 64 \\
\hline 30 & 0.2231 & 76 \\
\hline 40 & 0.1488 & 84 \\
\hline 50 & 0.1116 & 88 \\
\hline 80 & 0.2231 & 76 \\
\hline 100 & 0.4835 & 48 \\
\hline
\end{tabular}

Figure 4: Effect of CTAB on IE

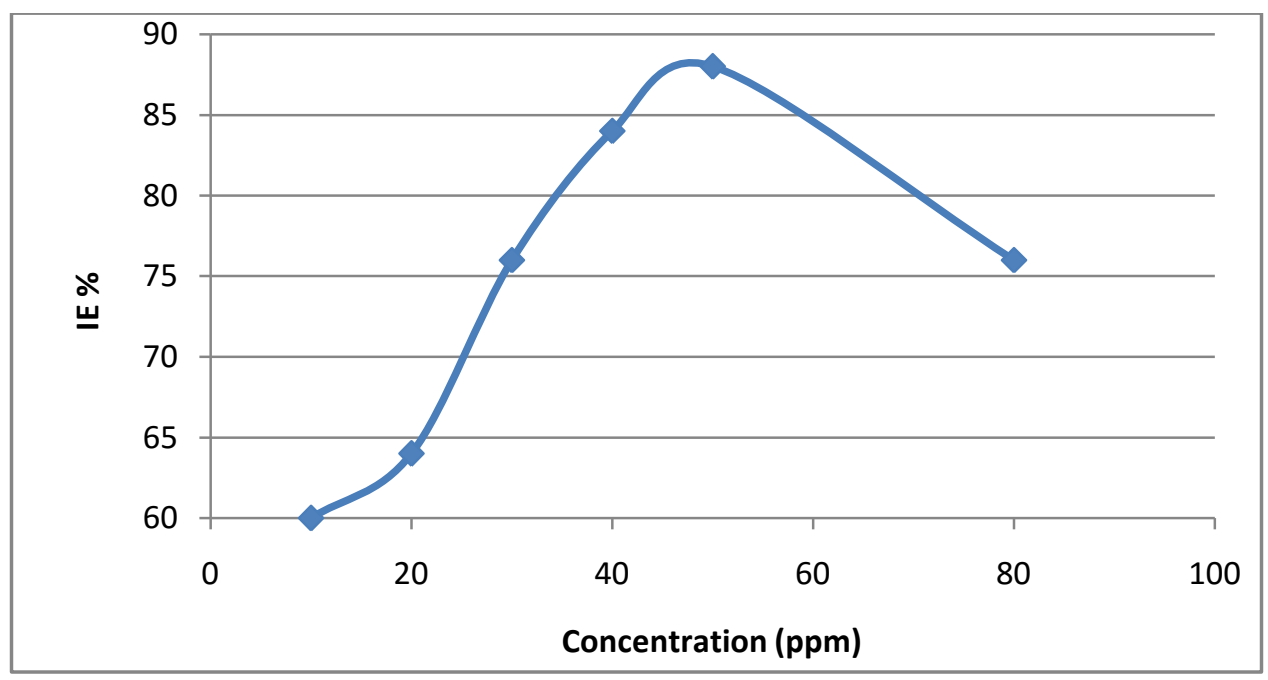


Table 5: Corrosion rate of mild steel in neutral aqueous environment $\left(\mathrm{Cl}^{-}=60 \mathrm{ppm}\right)$ in the presence and absence of inhibitor and the inhibition efficiencies obtained by weight loss method.

Inhibitor system: $\mathrm{DMBP}+\mathrm{Zn}^{2+}+\mathrm{CTAB}$

\begin{tabular}{|l|l|l|l|l|}
\hline $\begin{array}{l}\text { Conc.of DMBP } \\
(\mathrm{ppm})\end{array}$ & $\begin{array}{l}\text { Conc.of } \mathrm{Zn}^{2+} \\
(\mathrm{ppm})\end{array}$ & $\begin{array}{l}\text { Conc. of CTAB } \\
(\mathrm{ppm})\end{array}$ & $\begin{array}{l}\text { Corrosion rate } \\
(\mathrm{mmpy})\end{array}$ & $\begin{array}{l}\text { Inhibition } \\
\text { efficiency }(\%)\end{array}$ \\
\hline 0 & 0 & 0 & 0.9297 & - \\
\hline 0 & 90 & 0 & 0.3086 & 66.8 \\
\hline 200 & 0 & 0 & 0.3254 & 65 \\
\hline 200 & 90 & 0 & 0.2696 & 71 \\
\hline 200 & 90 & 10 & 0.2603 & 72 \\
\hline 200 & 90 & 20 & 0.1488 & 84 \\
\hline 200 & 90 & 30 & 0.1118 & 88 \\
\hline 200 & 90 & 40 & 0.0744 & 92 \\
\hline 200 & 90 & 50 & 0.3719 & 96 \\
\hline 200 & 90 & 100 & 0.2231 & 76 \\
\hline 200 & 90 & 200 & 0.2975 & 68 \\
\hline
\end{tabular}

Figure 5: Effect of $\mathrm{CTAB}$ on $\mathrm{IE}$ of $\mathrm{DMBP}+\mathrm{Zn}^{2+}$

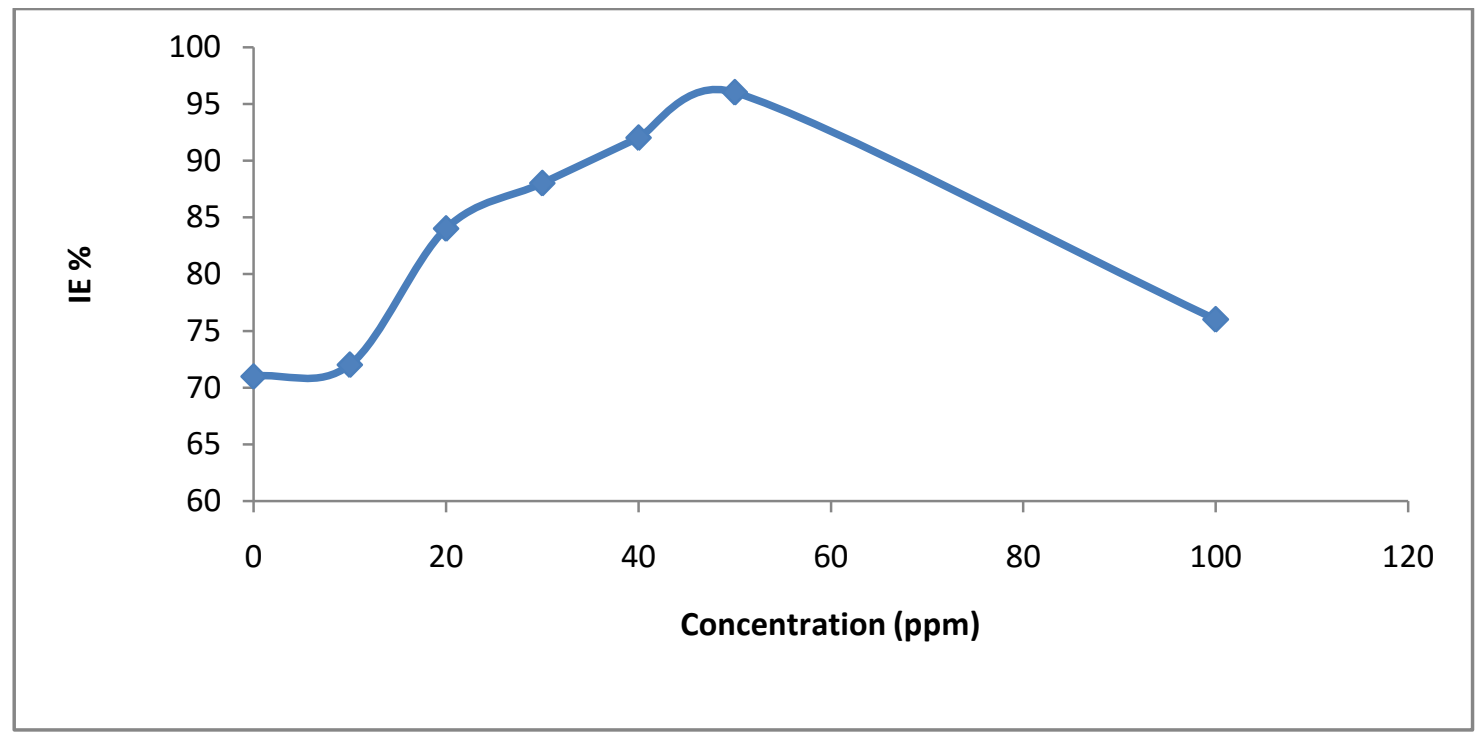


Table 6: Biocidal efficiencies of various environmental system: mild steel immersed in $\mathrm{DMBP}+\mathrm{Zn}^{2+}+\mathrm{CTAB}$

\begin{tabular}{|l|l|l|l|l|l|}
\hline $\begin{array}{l}\text { Conc. of } \mathrm{Cl}^{-} \\
\text {ion }(\mathrm{ppm})\end{array}$ & $\begin{array}{l}\text { Conc. of } \\
\mathrm{DMBP} \\
(\mathrm{ppm})\end{array}$ & $\begin{array}{l}\text { Conc. of } \\
\mathrm{Zn}^{2+}(\mathrm{ppm})\end{array}$ & $\begin{array}{l}\text { Conc. of } \\
\text { CTAB } \\
(\mathrm{ppm})\end{array}$ & $\begin{array}{l}\text { Colony } \\
\text { forming unit } \\
(\mathrm{CFU} / \mathrm{ml})\end{array}$ & $\begin{array}{l}\text { Biocidal } \\
\text { efficiency } \\
(\mathrm{BE} \%)\end{array}$ \\
\hline 60 & 0 & 0 & 0 & $1 \times 10^{7}$ & - \\
\hline 60 & 200 & 90 & 0 & $1 \times 10^{6}$ & 90 \\
\hline 60 & 200 & 90 & 10 & $2.4 \times 10^{3}$ & 99.99 \\
\hline 60 & 200 & 90 & 50 & Nil & 100 \\
\hline 60 & 200 & 90 & 100 & Nil & 100 \\
\hline 60 & 200 & 90 & 150 & Nil & 100 \\
\hline 60 & 200 & 90 & 200 & Nil & 100 \\
\hline 60 & 200 & 90 & 250 & Nil & 100 \\
\hline
\end{tabular}

Figure 6: Biocidal efficiency of $\mathrm{CTAB}$ as a function of number of colony forming unit in relating to concentration of biocide $\mathrm{CTAB}$

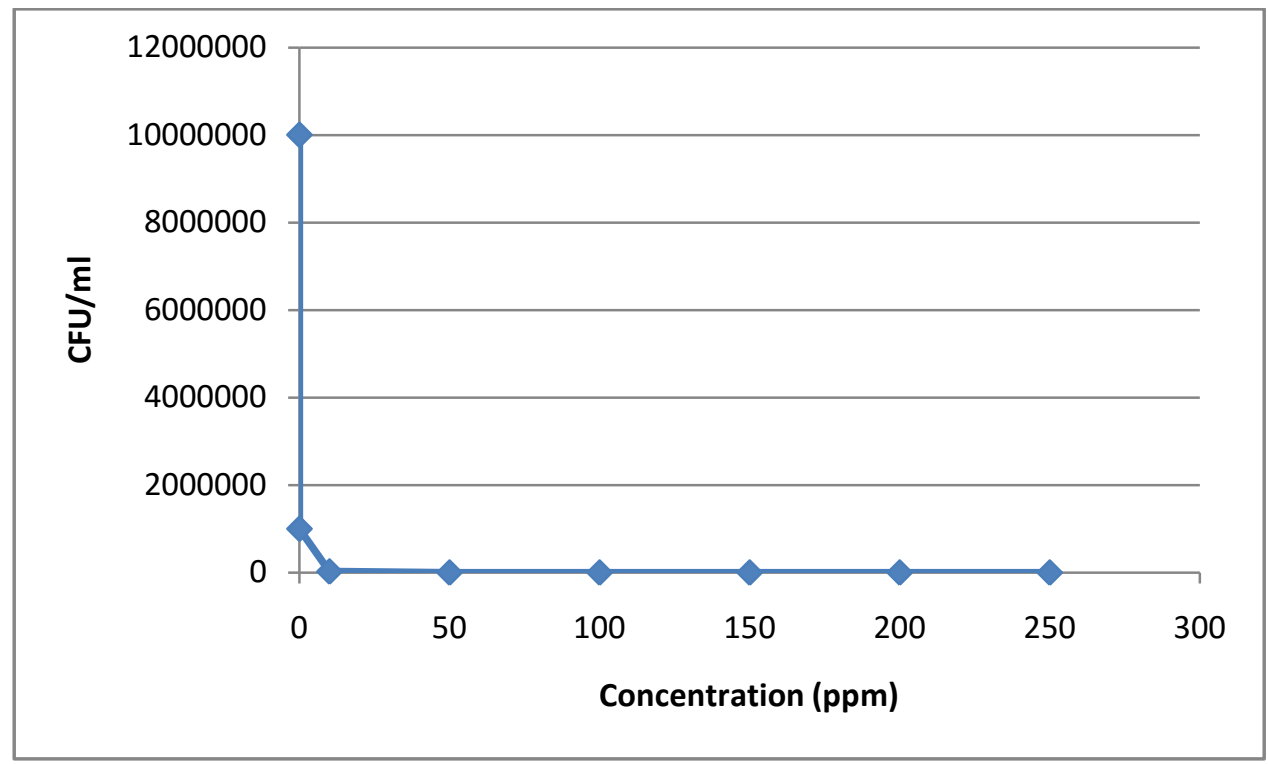


Figure 7: Schematic pictures of Bacterial colonies in petri dishes containing corrosive and inhibitor systems.

\section{CORRODED (CFU)}

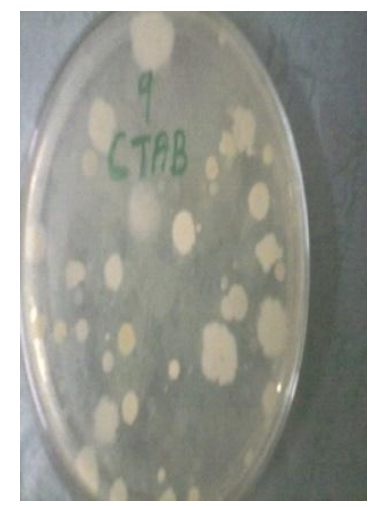

a

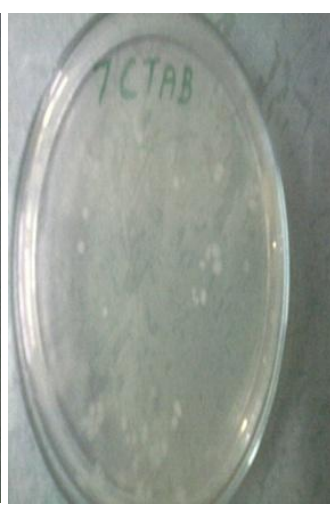

b
INHIBITED
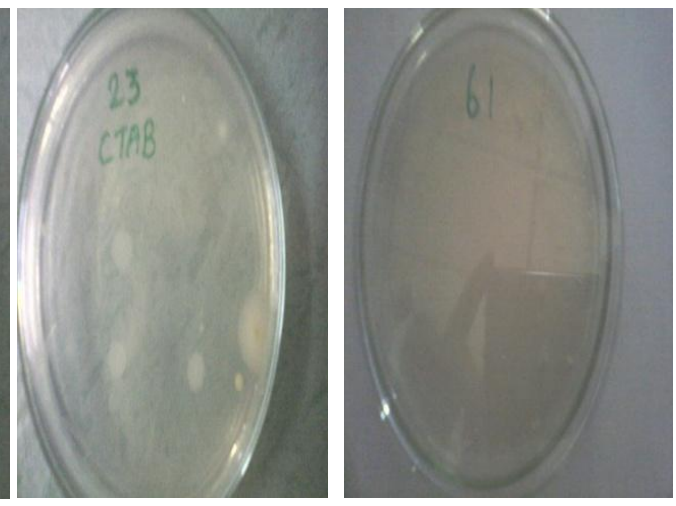

d

Figure 7a: $\mathrm{CFU} / \mathrm{ml}$ in $60 \mathrm{ppm} \mathrm{Cl}^{-}+0 \mathrm{ppm} \mathrm{CTAB}$

Figure 7b: CFU/ml in $60 \mathrm{ppm} \mathrm{Cl}^{-}+30 \mathrm{ppm} \mathrm{CTAB}$

Figure 7c: CFU/ml in $60 \mathrm{ppm} \mathrm{Cl}^{-}+40 \mathrm{ppm} \mathrm{CTAB}$

Figure 7d: CFU/ml in $60 \mathrm{ppm} \mathrm{Cl}^{-}+50 \mathrm{ppm} \mathrm{CTAB}$

\subsection{Biocidal efficiency of SDS on binary inhibitor $\left(\mathrm{DMBP}-\mathrm{Zn}^{2+}\right)$ system}

The biocidal efficiency of DMBP- $\mathrm{Zn}^{2+}$-SDS system is given in Table 9. It is found that SDS has very good biocidal efficiency in a wide concentration range (i.e., 10 to $250 \mathrm{ppm}$ ). It seems that SDS has biocidal activity as it aggregates together. The number of bacterial colonies formed as a function of concentration of SDS in presence of DMBP-Zn ${ }^{2+}$-SDS system is shown in Fig. 11. When 10 ppm of SDS along with the inhibitor DMBP- $\mathrm{Zn}^{2+}$ is added unacceptable value of $1.4 \times 10^{3} \mathrm{CFU} / \mathrm{ml}$ is counted. However,when $40 \mathrm{ppm}$ SDS of the same system has shown no sign of colonies in the system. It proves that a mixture of $60 \mathrm{ppm} \mathrm{Cl}^{-}, 200 \mathrm{ppm}$ DMBP-90 ppm $\mathrm{Zn}^{2+}-40 \mathrm{ppm}$ SDS, provides $100 \%$ biocidal efficiency. The $100 \%$ biocidal efficiency is evidenced by reported results in earlier works $(12,16)$ proved that the cationic surfactant SDS along with other organic and inorganic inhibitors may be used as an excellent biocide in cooling water systems. 
Table 7: Corrosion rate of mild steel in neutral aqueous environment containing SDS $\left(\mathrm{Cl}^{-}\right.$ $=60 \mathrm{ppm})$ in the absence of inhibitor and the inhibition efficiencies obtained by weight loss method.

\begin{tabular}{|l|l|l|}
\hline $\begin{array}{l}\text { Conc. of SDS } \\
(\mathrm{ppm})\end{array}$ & $\begin{array}{l}\text { Corrosion rate } \\
(\mathrm{mmpy})\end{array}$ & $\begin{array}{l}\text { Inhibition } \\
\text { efficiency }(\%)\end{array}$ \\
\hline 0 & 0.9297 & - \\
\hline 5 & 0.4463 & 52 \\
\hline 10 & 0.2603 & 72 \\
\hline 20 & 0.1960 & 80 \\
\hline 30 & 0.1488 & 84 \\
\hline 40 & 0.0744 & 92 \\
\hline 60 & 0.2603 & 72 \\
\hline 70 & 0.2975 & 68 \\
\hline
\end{tabular}

Figure 8: Effect of SDS on IE

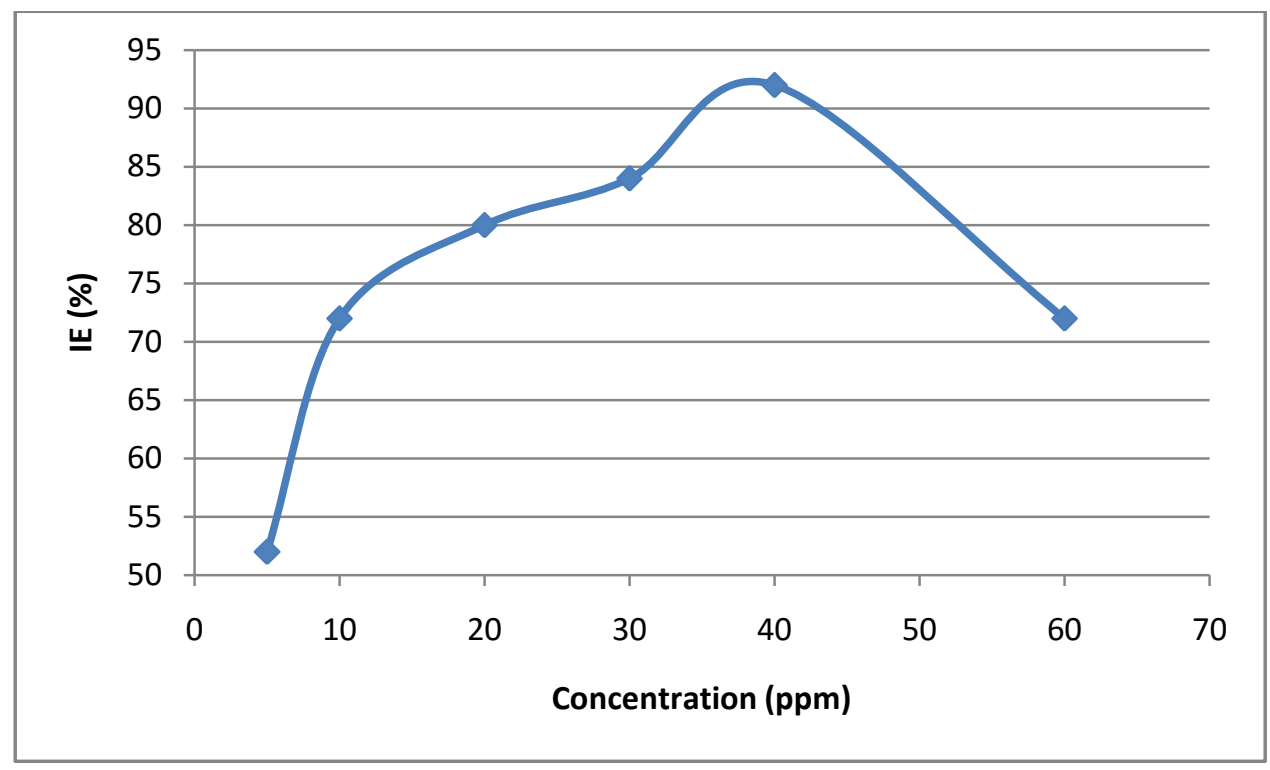

Table 8: Corrosion rate of mild steel in neutral aqueous environment $\left(\mathrm{Cl}^{-}=60 \mathrm{ppm}\right)$ in the presence and absence of inhibitor and the inhibition efficiencies obtained by weight loss method.

Inhibitor system: $\mathrm{DMBP}+\mathrm{Zn}^{2+}+\mathrm{SDS}$

\begin{tabular}{|l|l|l|l|l|}
\hline $\begin{array}{l}\text { Conc.of DMBP } \\
(\mathrm{ppm})\end{array}$ & $\begin{array}{l}\text { Conc.of } \mathrm{Zn}^{2+} \\
(\mathrm{ppm})\end{array}$ & Conc. of SDS & $\begin{array}{l}\text { Corrosion rate } \\
(\mathrm{mmpy})\end{array}$ & $\begin{array}{l}\text { Inhibition } \\
\text { efficiency }\end{array}$ \\
\hline 0 & 0 & 0 & 0.9297 & - \\
\hline 0 & 90 & 0 & 0.3086 & 66.8 \\
\hline 200 & 0 & 0 & 0.3254 & 65 \\
\hline 200 & 90 & 0 & 0.2696 & 71 \\
\hline 200 & 90 & 5 & 0.2231 & 76 \\
\hline 200 & 90 & 10 & 0.1859 & 80 \\
\hline 200 & 90 & 20 & 0.1488 & 84 \\
\hline
\end{tabular}


IRA-International Journal of Technology \& Engineering

\begin{tabular}{|l|l|l|l|l|}
\hline 200 & 90 & 30 & 0.1116 & 88 \\
\hline 200 & 90 & 40 & 0.0372 & 96 \\
\hline 200 & 90 & 70 & 0.1488 & 84 \\
\hline 200 & 90 & 150 & 0.2603 & 72 \\
\hline 200 & 90 & 200 & 0.3347 & 64 \\
\hline
\end{tabular}

Figure 9: Effect of SDS on IE of DMBP $+\mathrm{Zn}^{2+}$

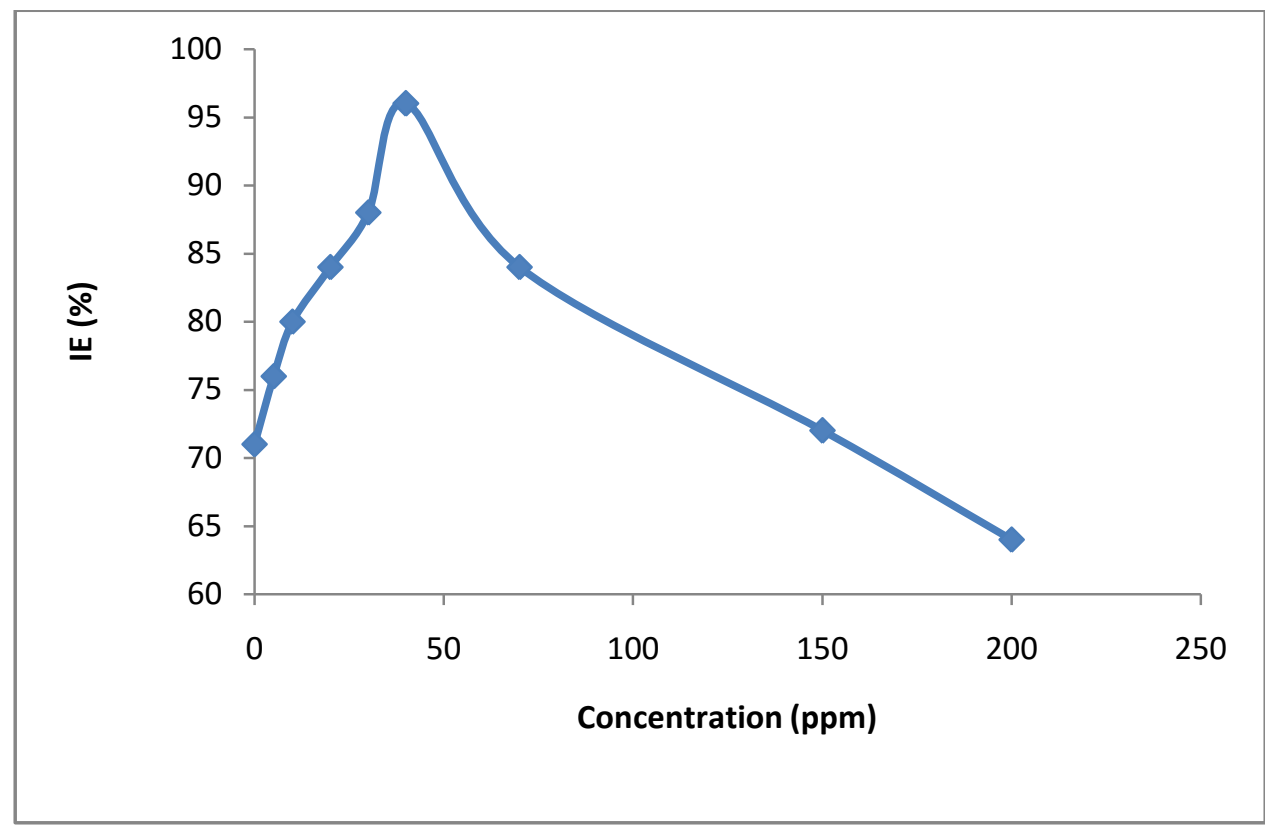

Table 9: Biocidal efficiencies of various environmental system: mild steel immersed in $\mathrm{DMBP}+\mathrm{Zn}^{2+}+\mathrm{SDS}$

\begin{tabular}{|l|l|l|l|l|l|}
\hline $\begin{array}{l}\text { Conc. of } \mathrm{Cl}^{-} \\
\text {ion }(\mathrm{ppm})\end{array}$ & $\begin{array}{l}\text { Conc. of } \\
\mathrm{DMBP} \\
(\mathrm{ppm})\end{array}$ & $\begin{array}{l}\text { Conc. of } \\
\mathrm{Zn}^{2+}(\mathrm{ppm})\end{array}$ & $\begin{array}{l}\text { Conc. of } \\
\text { SDS (ppm) }\end{array}$ & $\begin{array}{l}\text { Colony } \\
\text { forming unit } \\
(\mathrm{CFU} / \mathrm{ml})\end{array}$ & $\begin{array}{l}\text { Biocidal } \\
\text { efficiency } \\
(\mathrm{BE} \%)\end{array}$ \\
\hline 60 & 0 & 0 & 0 & $1 \times 10^{7}$ & - \\
\hline 60 & 200 & 90 & 0 & $1 \times 10^{6}$ & 90 \\
\hline 60 & 200 & 90 & 10 & $1.4 \times 10^{3}$ & 99.99 \\
\hline 60 & 200 & 90 & 40 & Nil & 100 \\
\hline 60 & 200 & 90 & 100 & Nil & 100 \\
\hline 60 & 200 & 90 & 150 & Nil & 100 \\
\hline 60 & 200 & 90 & 200 & Nil & 100 \\
\hline 60 & 200 & 90 & 250 & Nil & 100 \\
\hline
\end{tabular}


Figure 10: Biocidal efficiency of SDS as a function of number of colony forming unit in relating to concentration of biocide SDS

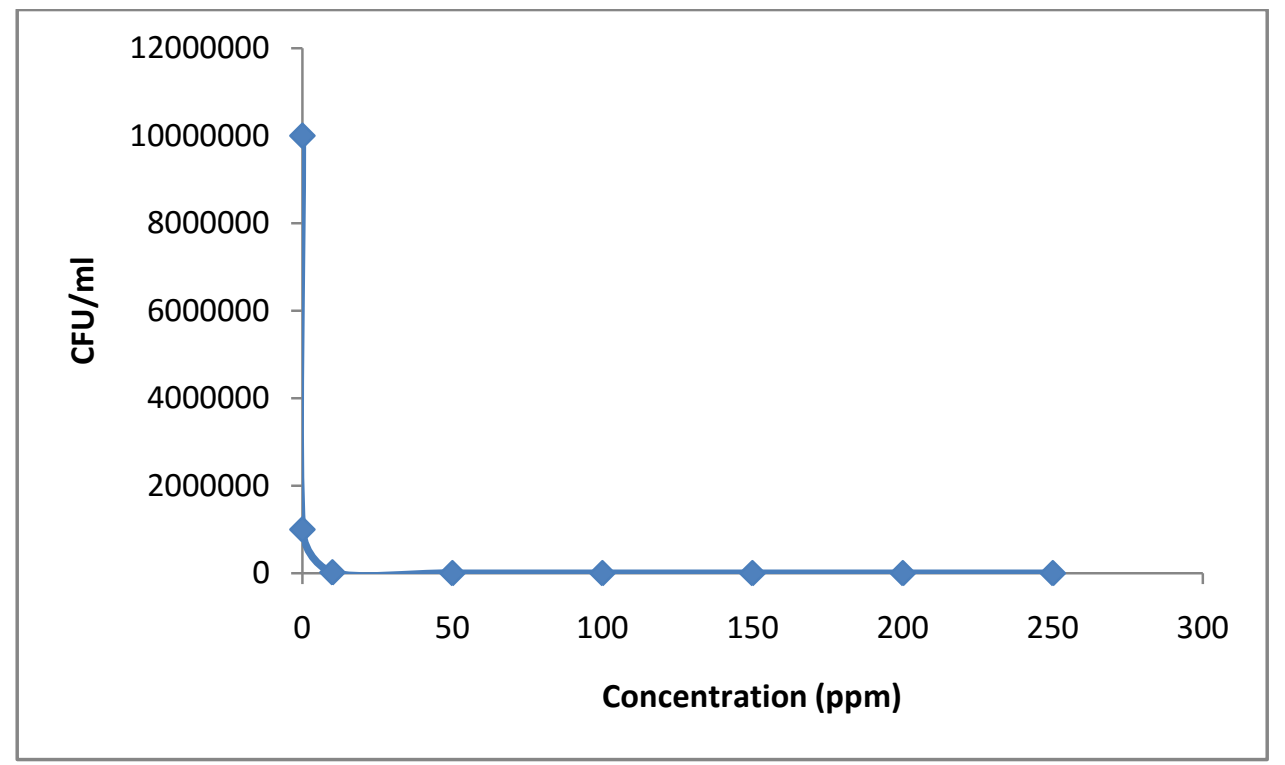

Figure 11: Schematic pictures of Bacterial colonies

CORRODED (CFU)

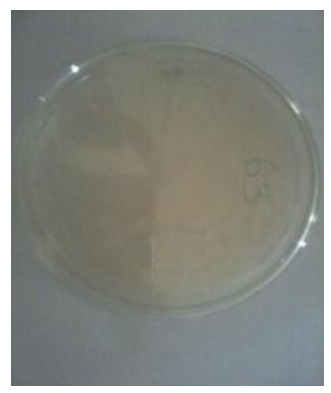

a

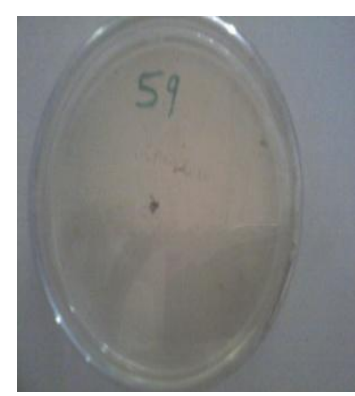

b
INHIBITED
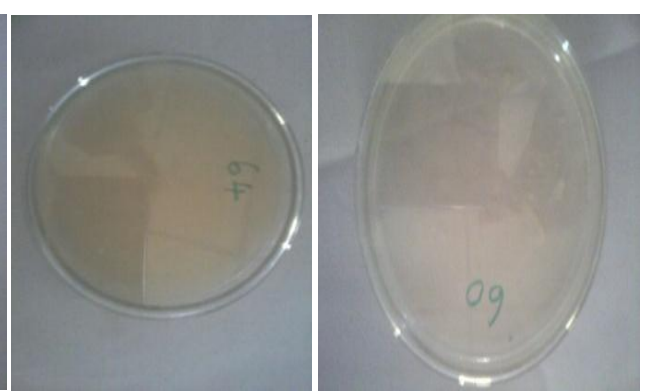

d

Figure 11a: CFU/ml in $60 \mathrm{ppm} \mathrm{Cl}^{-}+0 \mathrm{ppm}$ SDS

Figure 11b: CFU/ml in $60 \mathrm{ppm} \mathrm{Cl}^{-}+30 \mathrm{ppm}$ SDS

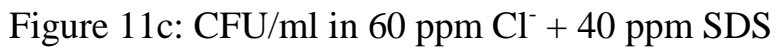

Figure 11d: $\mathrm{CFU} / \mathrm{ml}$ in $60 \mathrm{ppm} \mathrm{Cl}^{-}+50 \mathrm{ppm} \mathrm{SDS}$

\subsection{FT-IR Spectral Study}

In pure DMBP the P-O stretching frequency appears at $1058 \mathrm{~cm}^{-1}$. The $\mathrm{P}-\mathrm{OH}$ group causes absorption at $1036 \mathrm{~cm}^{-1}$ and $\mathrm{P}(\mathrm{O})(\mathrm{OH})$ group at $3460 \mathrm{~cm}^{-1}$. The absorption band at $1058 \mathrm{~cm}^{-1}$ represents $\mathrm{P}-\mathrm{O}$ stretching frequency. The absorption at $1299 \mathrm{~cm}^{-1}$ represents $\mathrm{P}=\mathrm{O}$ stretching. The absorption band due to the bending of O-P-O appears at $496 \mathrm{~cm}^{-1}$, $569 \mathrm{~cm}^{-1}$ and $642 \mathrm{~cm}^{-1}$. The increase in $\mathrm{P}=\mathrm{O}$ stretching frequency of the ester from 1299 $\mathrm{cm}^{-1}$ to $1314 \mathrm{~cm}^{-1}$ relative to the oxides, results from the electro negativity of the attached 
alkoxy groups. Thus FTIR spectrum of DMBP with molecular formula $\mathrm{C}_{12} \mathrm{H}_{19} \mathrm{O}_{3} \mathrm{P}$ is characterized by the FTIR spectrum.

The FTIR spectrum of the film formed on the surface of the carbon steel after immersion in the test solution containing DMBP- $\mathrm{Zn}^{2+}$ and $\mathrm{Cl}^{-}$is shown in Figure 12.The shift $\mathrm{P}-\mathrm{O}$ frequency from $1058 \mathrm{~cm}^{-1}$ to $1044 \mathrm{~cm}^{-1}$ indicates that the oxygen atom of the P$\mathrm{O}$ group has coordinated with $\mathrm{Fe}^{2+}$ resulting in the formation of $\mathrm{Fe}^{2+}-\mathrm{DMBP}$ complex formed on the anodic sites of the metal surface. The $\mathrm{P}=\mathrm{O}$ stretching frequency increased from $1299 \mathrm{~cm}^{-1}$ to $1335 \mathrm{~cm}^{-1}$ it also conforms the complex formation between the inhibitor and $\mathrm{Fe}^{2+}$. The peak at $3343 \mathrm{~cm}^{-1}$ due to $\mathrm{OH}$ stretching. The band due to $\mathrm{Zn}-\mathrm{O}$ stretch appears at $1314 \mathrm{~cm}^{-1}$. These results is confirmed the presence of $\mathrm{Zn}(\mathrm{OH})_{2}$ deposited on the cathodic sites of the metal surface (17).

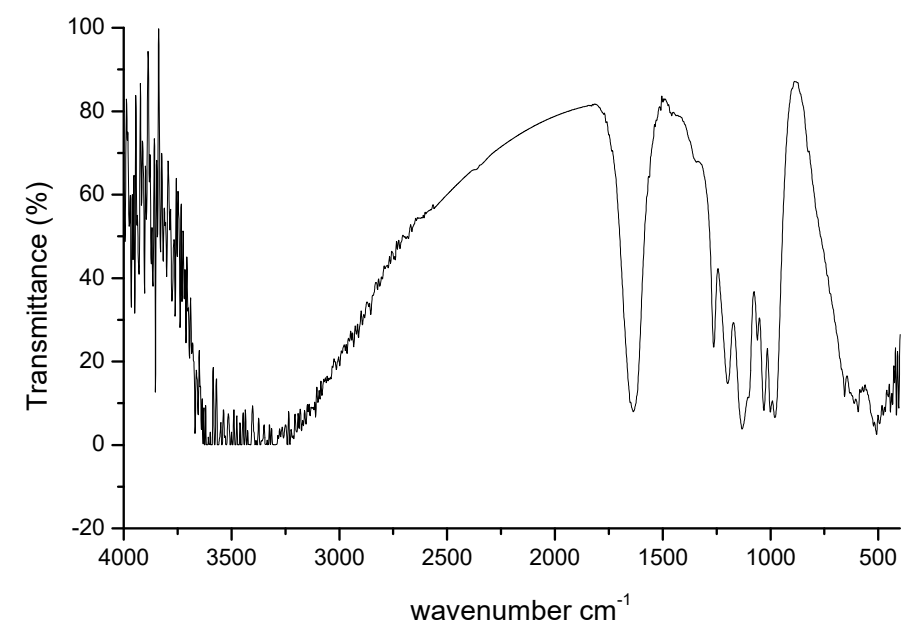

\subsection{Surface morphology study}

The surface morphologies of carbon steel specimen in aqueous solution containing $60 \mathrm{ppm} \mathrm{Cl}^{-}$ion in the presence and absence of inhibitor after 3 hours of immersion period are examined using a Scanning Electronic Microscopy (SEM) is displayed in fig 12-a - 12d. In the absence of inhibitor Fig 12(a) a very smooth surface is obtained due to the absence of corrosive products on the surface. In the presence of 60 ppm $\mathrm{Cl}^{-}$ion (corrosive medium) (Fig 12(b)) a very rough surface is observed due to rapid corrosion attack of carbon steel by chloride anions. There are few pits surrounded by iron oxide layer which almost fully covers the carbon steel surface, revealing that pit formation under these conditions occurs continuously during the exposure period while iron oxide builts up over the surface in the presence of the inhibitor (fig 12(c)) the pits and roughness are reduced, very smooth surface is observed indicating the formation of the protective film. Figure 12 (d) and 12 (e) shown that CTAB, SDS and inhibitor combination act as good system for bacterial control as well as corrosion control. 

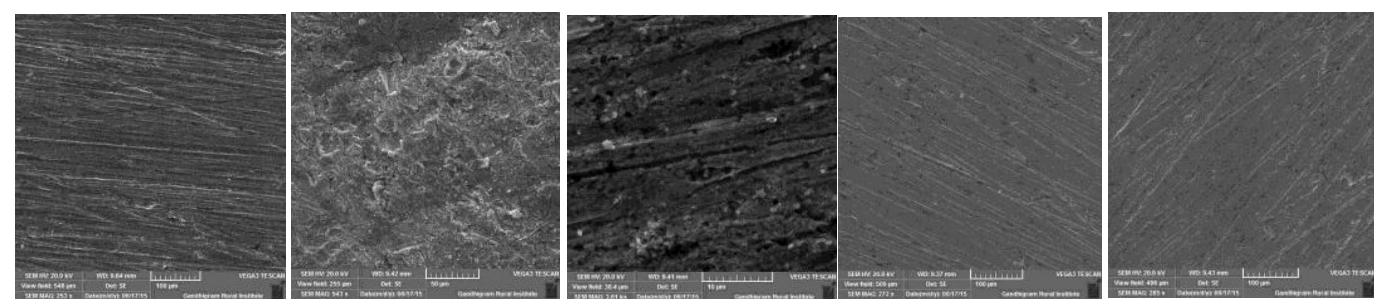

SEM photograph of

Figure 12(a):polished mild steel

Figure 12(b):mild steel specimen immersed in aqueous medium containing $60 \mathrm{ppm} \mathrm{Cl}$ ion

Figure 12(c): mild steel exposed aqueous medium containing $60 \mathrm{ppm} \mathrm{Cl-ion} \mathrm{and} \mathrm{inhibitor}$ solutions (200 ppm DMBP + 90 ppm $\mathrm{Zn}^{2+}$ ion)

Figure 12(d): mild steel exposed aqueous medium containing $60 \mathrm{ppm} \mathrm{Cl-ion} \mathrm{and} \mathrm{inhibitor}$ solutions (200 ppm DMBP + 90 ppm Zn ${ }^{2+}$ ion +50 ppm CTAB).

Figure 12(e): mild steel exposed aqueous medium containing $60 \mathrm{ppm} \mathrm{Cl}$-ion and inhibitor solutions (200 ppm DMBP + $90 \mathrm{ppm} \mathrm{Zn}^{2+}$ ion + $\left.40 \mathrm{ppm} \mathrm{SDS}\right)$.

\section{Conclusion}

The following conclusion may be drawn from the study

- Results obtained from the experimental data shows that DMBP act as a effective inhibitor on mild steel in aqueous medium

- The corrosion process was inhibited by adsorption of the DMBP on the metal surface.

- The formulation $(60 \mathrm{ppm}+200 \mathrm{ppm}+90 \mathrm{ppm}+50 \mathrm{ppm}) \mathrm{Cl}^{-}+\mathrm{DMBP}+\mathrm{Zn}^{2+}+$ CTAB had $96 \%$ corrosion inhibition efficiency

- The formulation $(60 \mathrm{ppm}+200 \mathrm{ppm}+90 \mathrm{ppm}+40 \mathrm{ppm}) \mathrm{Cl}^{-}+\mathrm{DMBP}^{2} \mathrm{Zn}^{2+}+\mathrm{SDS}$ had $96 \%$ corrosion inhibition efficiency

- The CTAB and SDS are enhanced the microbial corrosion inhibition on the mild steel surface in the aqueous medium.

- $\quad$ SEM conform the presence of a protective film on the mild steel surface. The bacterial enumeration has been reduced by the addition of CTAB and SDS to the inhibitor system.

\section{References}

1. J.Horigne, H.Bader, J.Water Res., 17 (1983) 173.

2. P.M.Williams, R.J.Baldwin, K.J.Robertson, J.Water.Res., 12 (1978) 358.

3. M.El Azhar, B.Mernare, M.Traisnel, F.Bentiss, M.Lagrenee, Corros.Sci., 43(2001) 2227.

4. Caroline M.Murira, Christian Punckt, Hannes.C.Schniepp, Boris Khurid and Ilhan A.Aksay Langmuir 2008, 24, 14269-14275.

5. E.Kálmán, F.H.Kármán, J.Telegdi, B.Várhegyi, J.Balla and T.Kiss (Inhibition efficiency of n-containing carboxylic and carboxy-phosphonic acids). Corrosion Science, 35: 1477-1481, 1993.

6. G.Wranglen, Introduction to corrosion and protection of metals, London, UK: Chapman and Hall; 236, 1985.

7. Q.B.Zhang, Y.X.Hua, Corrosion inhibition of mild steel by alkylimidazolium ionic liquids in hydrochloric acid, Electrochimica Acta 54, 1881-1887, 2009. 
8. D.Vanloyen, Matls.and Corr., Werkstoffe Und Korr., 40 (1989) 599.

9. P.R.Puckorius, Matls. Perf., 22 (1983) 19.

10. W.P.Iverson, Matls. Perf., 22 (1984) 28.

11. M.Akaushal and G.Singh, Proc.Int.Convention on Surf.Engg., Bangalore, India (2004) 179.

12. S.Rajendran, A. John Amalraj, M.Sundaravadivelu and A.Peter Pascal Regis, Bull.electrochem., 17 (2001) 179.

13. A.Marshall, B.Greares and D.M.Everitt, Matls. Perf., 5 (1986) 45.

14. B.E.Moriarity, Matls. Perf., 1 (1990) 45.

15. S.M.A. Shibli and V.S.Saji, Corr.Prev \& Control, 50 (2003) 136.

16. S.Rajendran, R.M.Joany and N.Palaniswamy, Corr. Rev., 20 (2002) 231.

17. R.Kalaivani, B.narayanaswamy, J.A.Selvi et.al, Port. Electrochim. Acta, 27, 177, 2009. 